\title{
Thyroid surgery in an elderly population
}

\author{
F Viano $^{1 *}$, C Terranova ${ }^{2}$, S Ricciardi ${ }^{1}$, E Mion ${ }^{1}$, R Gianesini ${ }^{1}$, S Faccin ${ }^{1}$, M Giachetti ${ }^{3}$, M Masciavè ${ }^{4}$, L De Santis ${ }^{1}$ \\ From de Senectute: Age and Health Forum \\ Catanzaro, Italy. 5-7 December 2009
}

\section{Background}

The increase in life expectancy over the past 20-30 years has caused major changes in the average age of patients hospitalized in surgical wards. The thyroid disease is common in the elderly population [1]. Elderly patients, especially with co-morbidity, are at increased operative risk [2]; the pre-operative selection and perioperative monitoring have to be more accurate than in young patients; a lack of compentence in these phases can result in clinical and medico-legal consequences.

The aim of the study was to present a retrospective analysis of 124 elderly patients who had undergone thyroid surgery at the Department of Surgery Hospital of Valdagno.

\section{Patients and method}

The study included 124 patients ( 26 male, 98 female), aged above 60 (average age 67,34 maximum 60 and 80 years old) that undergone thyroid surgery between 2005 and September 2009 (Table 1). 24 patients were ASA 1, 82 ASA 2 and 18 ASA 3 (Table 1).

Endocrinological examination, evaluation of the mobility of the vocal cords, thyroid hormones dosing and ultrasound evaluation of the thyroid, were performed before the operation.

\section{Table 1}

\begin{tabular}{lll}
\hline & $\mathbf{N}^{\mathbf{0}}$ & $\%$ \\
\hline Male & 26 & 21 \\
Female & 98 & 79 \\
Age (range) & $67(60-80)$ & \\
ASA score \% & & \\
1 & 24 & 19 \\
2 & 82 & 67 \\
3 & 18 & 14 \\
\hline
\end{tabular}

'Department of Surgery, Division of Surgery, Ospedale "San Lorenzo", Valdagno, Italy
Table 2 Surgical indications

\begin{tabular}{ll}
\hline Multinodular goiter & $\mathbf{5 2}$ \\
Mediastinic Goiter & 19 \\
Toxic Multinodular goiter & 12 \\
Graves' disease & 9 \\
Adenoma & 4 \\
Papillary carcinoma & 14 \\
Follicolar Cancer & 6 \\
\hline
\end{tabular}

113 total thyroidectomy and 11 hemityroidectomy were carried out; 106 patients were operated on for benign diseases (toxic and non toxic multinodular goiter, Graves' disease, adenoma) 18 for malignant disease (follicular cancer, papillary carcinoma) (Table 2).

\section{Results}

The average hospitalization length was 6.1 days (5-8 days). Complications occurred in 12 patients (9.6\%): 1 case of transient bilateral vocal cord paralysis requiring the execution of a tracheostomy with complete resolution after 10 days, 10 cases of transient hypocalcemia treated with calcium and vitamin D3 supplements and 1 case of postoperative bleeding. There was no postoperative mortality.

\section{Conclusions}

Population ageing will determine an increase of thyroid surgical procedure in elderly patients.

The analysis of the data provided showed that thyroid surgery in the elderly can be performed with satisfactory results with an incidence of complications similar to those observed in young patients [3].

\section{Author details}

'Department of Surgery, Division of Surgery, Ospedale "San Lorenzo",

Valdagno, Italy. ${ }^{2}$ Department of Environmental medicine and public health, Section of Legal Medicine, Hospital-University of Padova, Italy. ${ }^{3}$ Department of Internal Medicine, Endocrinology service, Ospedale "San Lorenzo",

Valdagno, Italy. ${ }^{4}$ Department of Emergency Medicine, Ospedale di Ivrea (TO), Italy. 
Published: 19 May 2010

\section{References}

1. Denham MJ, Willis EJ: A Clinico-Pathological Survey of Thyroid Glands in Old Age. Gerontology 1980, 26:160-166.

2. Turrentine FE, Wang H, Simpson VB, Jones RS: Surgical risk factors, morbidity and mortality in elderly patients. J Am Coll Surg. 2006, 203(6):865-77.

3. Trottier DC, Barron P, Moonje V, Tadros S: Outpatient thyroid surgery: Should patients be discharged on the day of their procedures? I Can Chir 2009, 3:182-186.

doi:10.1186/1471-2318-10-S1-A37

Cite this article as: Viano et al.: Thyroid surgery in an elderly population. BMC Geriatrics 2010 10(Suppl 1):A37.

Submit your next manuscript to BioMed Central and take full advantage of:

- Convenient online submission

- Thorough peer review

- No space constraints or color figure charges

- Immediate publication on acceptance

- Inclusion in PubMed, CAS, Scopus and Google Scholar

- Research which is freely available for redistribution

Submit your manuscript at www.biomedcentral.com/submit 